\title{
The Influence of Jogjakarta Outer Ring Road Development Plan on the National Roads in the Special Region of Yogyakarta
}

\author{
Prima J. Romadhona*, Afan Gaffarudin, Thareq I. Tanza, Arief R. Wiwaha \\ Department of Civil and Environmental Engineering, Universitas Islam Indonesia, INDONESIA \\ Jalan Kaliurang km. 14,5 Yogyakarta \\ *Corresponding authors: prima_dhona@uii.ac.id
}

SUBMITTED 22 April 2020 REVISED 5 August 2020 ACCEPTED 18 September 2020

\begin{abstract}
The development of Jogja Outer Ring Road (JORR) has been issued by the government as one of the possible alternatives to deal with traffic jams. The proposed ring road aims to expand the existing 7 meters width road constructed in 2018 to 14 meters, and it is expected to pass through 22 districts in 3 regencies. A total of 4 main streets, namely Solo-Jogja st, Kaliurang St, Magelang St, and Palagan Tentara Pelajar St, were set as the objects of comparison to the existence of JORR, with VISSUM software used to analyze three probabilities, namely 1) without JORR (2018), 2) JORR of government route (2026), and 3) actualized JORR with an alternative route (2026). The result showed that based on the MoT standard in Indonesia, the V/C ratio of four surrounding roads with JORR was 5 times better than others. In addition, 3 roads performed better than the existing JORR. Therefore, based on this study, the V/C ratio of Solo-Jogja St located at the eastern part of Kalasan district is likely to decrease by $8.79 \%$, with the actualization of JORR and $60.78 \%$ when used as an alternate route. Furthermore, there is a possible increase in performance by $6.55 \%$ with the actualization of JORR and $49.42 \mathrm{when}$ used as an alternate road. Subsequently, at the southern part, the performance was raised by $16.25 \%$, and when used as an alternate road, a percentage of $5.27 \%$ was achieved. In conclusion, due to the strength and weaknesses of JORR as alternative routes, additional suggestions are proposed, such as traffic management and actualization of public transport.
\end{abstract}

KEYWORDS Jogjakarta Outer Ring Road; The Number of V/C; Speed; Gravity Method; PTV Visum.

(c) The Author(s) 2021. This article is distributed under a Creative Commons Attribution-ShareAlike 4.0 International license.

\section{INTRODUCTION}

Yogyakarta is one of Indonesia's most famous and visited tourist destinations due to its rich culture and scenic panorama. Furthermore, the area also consists of many schools and higher education institutions, attracting students from various towns. These factors are some of the causes of population explosion, thereby leading to a yearly increase in private vehicle owners. Therefore, to decongest the roads, the Jogja Outer Ring Road (JORR) was developed to eliminate the number of traffic jams in the downtown, which was predicted to have increased due to population growth (Stopher, 2004). However, JORR was converted to an arterial road due to the rapid regional development of ring roads in Yogyakarta to ease traffic congestion (Sánchez-Medina, Galán-Moreno, and Rubio-Royo, 2010).

For these reasons, the government offered a solution to traffic jams by building an outer ring road in Yogyakarta, named Jogja Outer Ring Road
(JORR). This road extends the existing road's width from 7 to 14 meters, with an estimated total length of 72.2 kilometers. This project is proposed to pass through 10 districts in Sleman (Prambanan, Berbah, Kalasan, Cangkringan, Pakem, Ngemplak, Turi, Tempel, Seyegan, and Minggir), 3 in Kulonprogo (Kalibawang, Nanggulan, and Sentolo) and 9 in Bantul (Sedayu, Pandak, Pajangan, Bantul, Jetis, Imogiri, Pleret, Piyungan, and Dlingo). The road was altered to meet traffic lights' traffic needs, roundabout, or parking lots of the specified location (Fontes et al., 2015). Furthermore, it was estimated that traffic congestion and accidents have an inverse relationship, therefore, they are a dilemma for transport policymakers (Wang, Quddus, and Ison, 2009). The proposed JORR project is estimated to be completed within 5-6 years, and it is supposed to decrease the traffic density in the main road at Jogjakarta (Jain, Sharma and Subramanian, 2012). 
Transportation modeling is necessary to investigate travel movements' transformation by utilizing the PTV VISUM software, after stipulating the target road for outer ring road construction. Some parameters need to be adjusted in order to simulate the existing condition of traffics on roads (Fontes et al., 2015; Hollander and Liu, 2008). PTV VISUM is a software specifically designed by PTV Group based in Germany and used to model and evaluate a transportation system in urban, metropolitan, and regional areas. It is also used to analyze the road contribution or performances based on service level and analyze road performance to determine the traffic volume within a particular period. Some research stated that PTV VISUM is used as a traffic modeling in some areas such as at Banda Aceh (Hendra, 2017), Samarinda City (Praditya, 2016), Bangka island (Yunus, 2018), Palembang city (Fuady, 2015 and Arliansyah, 2017) and Yogyakarta, where it is used to predict the effect of airport relocation to the surrounds road network (Fitrada, Munawar, and Dewanti 2019). PTV VISUM is also used to model traffic flows in some scenarios, such as road network changes or patterns, to achieve better performance (Grigonis, 2014, Taplin, 1999, and Yatski, 2007).

Therefore, in order to identify the transformation pattern that occurs along with the construction of JORR, a study on the performance of existing roads is urgently needed to determine the $\mathrm{V} / \mathrm{C}$ ratio of national roads. This research was intended to determine the $\mathrm{V} / \mathrm{C}$ ratio of national roads around the city center, such as in front of Kalasan district, State Electricity Company, Hyatt Hotel, and Wahidin Court located in Solo-Jogja St, Kaliurang St, Palagan Tentara St, and Magelang St. All targets were assumed under the condition of existing and post-construction of JORR in 2026 while proposing an alternate road.

Some studies analyzed the transportation system in city centers. The results provided some solutions such as the rearrangement of public transport ( Gulhan, 2014) and determining ways to reduce traffic demand (Lindsney and Verhoef, 2001).

\section{ROAD PERFORMANCE}

According to the Directorate General of Bina Marga, Ministry of Transportation in Indonesia (1997), road performance refers to a quantitative measure used to define roads' operational conditions, which covers density and delay time. One of the indicators used to determine the congestion level is the number of vehicles and road capacity. However, despite the increasing need to modify and reduce road congestion, research on the required methods does not systematically exist (Çolak, Lima, and González, 2016).

\subsection{Volume Capacity Ratio}

Volume capacity ratio compares the vehicle volume on the road with the remaining space for others within a specific time frame or in accordance with the road capacity (Transportation Research Board, 2000). Therefore, when the comparison is greater, it means that the traffic service is inadequate. According to O'Flaherty (1997), city roads' capacity refers to a maximum number of vehicles that are allowed to pass through a section within an hour and under particular traffic conditions. The term 'capacity' is defined as the maximum flow to vehicles in a specific road point that can last for an hour under specific conditions. However, there were many types of research on road capacity in some urban areas that are affected by the number of traffic volumes in the related area (Gajjar and Mohadash, 2016; Tennøy A et al., 2019; Rao, M.A, et al., 2017).

$V / C$ ratio $=\frac{V}{C}$

In Equation (1), $V / C$ ratio denotes volume capacity ratio, $V$ denotes traffic volume $(\mathrm{PCE} / \mathrm{h})$, and $C$ is road capacity (PCE/h).

\subsection{Flow Speed (FV)}

According to Hobbs (1974), speed is defined as the rate of movement shown by vehicles in accordance with the distance reached per unit time $(\mathrm{km} / \mathrm{h})$. Therefore, free-flow speed $(\mathrm{FV})$ refers to the speed reached when the flow level is zero. In other words, it is related to the preferred speed that the drivers intend to reach when 
driving without any interference from other road users is shown in Equation (2).

$F V=\left(F V_{0}+F V_{W}\right) \times F F V_{S F} \times F F V_{C S}$

Where $F V$ denotes the free-flow speed of light vehicle under the field conditions $(\mathrm{km} / \mathrm{h}), F V_{0}$ denotes basic free-flow speed $(\mathrm{km} / \mathrm{h}), F V_{w}$ is a factor of speed adjustment for traffic road width $(\mathrm{km} / \mathrm{h}), F F V_{S F}$ is a factor of speed adjustment for side barriers, and $F F V_{C S}$ is a factor of speed adjustment for city size.

\section{RESEARCH METHOD}

\subsection{Location}

In terms of location, this research was carried out at the main streets of Yogyakarta, as follows

1. Solo-Yogyakarta St, in front of Kalasan district

2. Kaliurang St, in front of the State Electricity Company

3. Palagan Tentara St, in front of Hyatt Hotel

4. Magelang St, in front of Wahidin Court.

\subsection{Data}

Secondary data on traffic volumes, road capacities, speed, and origin-destination matrix (OD matrix) were obtained from the Department of Transportation (DoT) in Yogyakarta from 20152018. Data on population, vehicle ownership, Gross Regional Domestic Product, and several companies and schools in the Sleman Regency were collected from the Central Bureau of Statistics. These data were obtained from construction drawings, field surveys, geographical information system (GIS) files, and aerial photographs (Dowling, Skabardonis, and Alexiadis, 2004). Furthermore, the calibrations of traffic in 2026 were calculated based on vehicle ownership growth.

\subsection{Trip Production and Trip Attraction}

This model can be used to analyze the number of vehicles and population entering or leaving a destination, as well as the value of Gross Regional Domestic Product. This sort of model is necessary to determine the prospective number of movements in each of the zones. Furthermore, a multiple linear regression analysis is used as a statistical method to study the relationship between the characteristics of the issues under investigation. According to Ortuzar (2011), this method comprises independent (x) and dependent (y) variables.

\subsection{Unconstrained Gravity Method}

In the origin-destination matrix, the number of prospective trips can be conjectured based on the current data and traffic flow growth factor. This research utilized the gravity method by assuming the characteristics of trip production and attraction can be linked to some origin point parameters, such as population and the core value of origin-destination matrix, which were also related to the distance, time, and cost (Tamin, 1997).

The road trip pattern between land-use parcels or traffic zones was determined using an appropriate analytical technique (Thamizh Arasan, Wermuth, and Srinivas, 1996). This is an unlimited method, which means that it does not require the movement value in each zone to be at the level of the predicted production phase.

\subsection{PTV VISUM Software}

PTV VISUM is a civil engineering software developed by PTV Group based in Germany (PTV, $A G, 2011)$ for transportation analysis. The main utility of PTV VISUM lies in its basic capability to design a model for transportation issues at the macro level. Additionally, PTV VISUM offers the planners with a variance of direct comparison between the existing and foreseen conditions indicated by the traffic transformation that occurs within the road and transit networks. This research proposed an experiment design model to select the parameters, which were searched optimally using two genetic algorithms (Jimenez et al., 2016)

\section{ANALYSIS AND DISCUSSION}

The DoT data obtained from 2015 to 2018 showed poor traffic performance in some Yogyakarta locations. Figure 1 provides information on the fluctuated comparison of Volume and capacity in some streets. In the beginning, Solo St had the lowest comparison than others, which means it 
had the best performance, however, a year later, the west side became the most congested street. On the other hand, the other street had a stable condition because the $\mathrm{V} / \mathrm{C}$ ratio remained less than 0.8. Nevertheless, the critical condition is likely to make them worst, assuming there were no actions related to traffic management. In addition, Figure 2 shows that the traffic matrix per zone in Yogyakarta surrounds the research area. Therefore, the load of the traffic network based on OD matrix is shown in Figure 3.

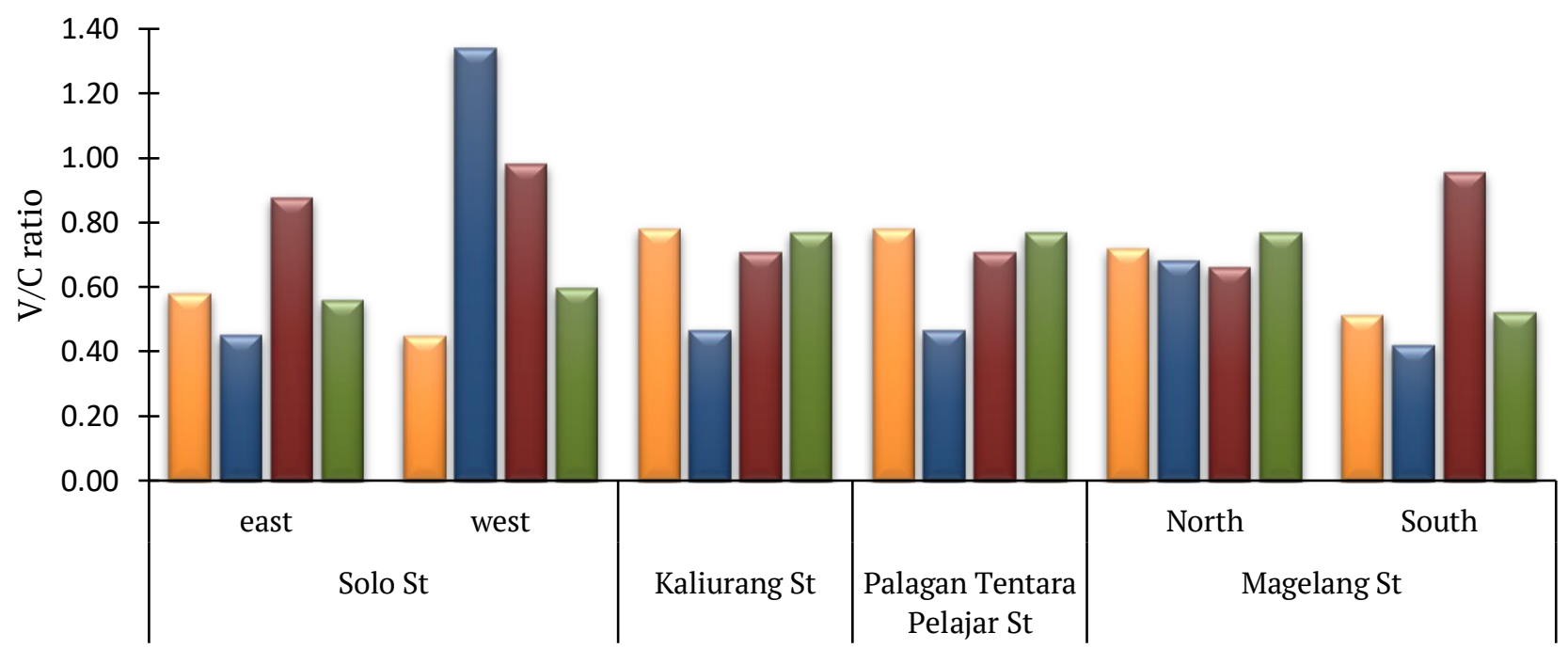

Research Location

$\square 2015 \square 2016 \square 2017 \square 2018$

Figure 1: V/C Ratio in Some Arterial Roads in Yogyakarta from 2015-2018

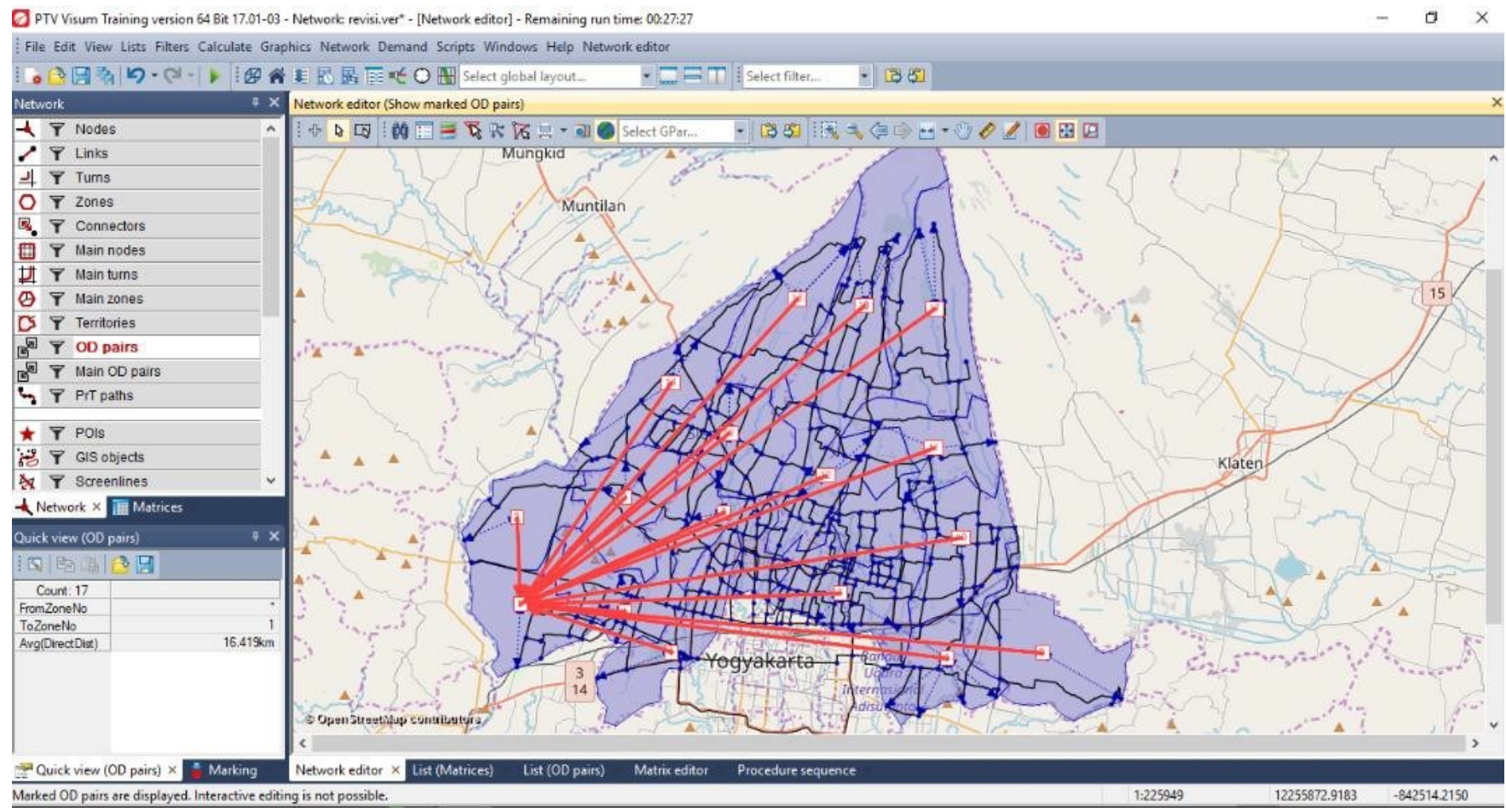

Figure 2: Matrix Data in Each Connected Zone 


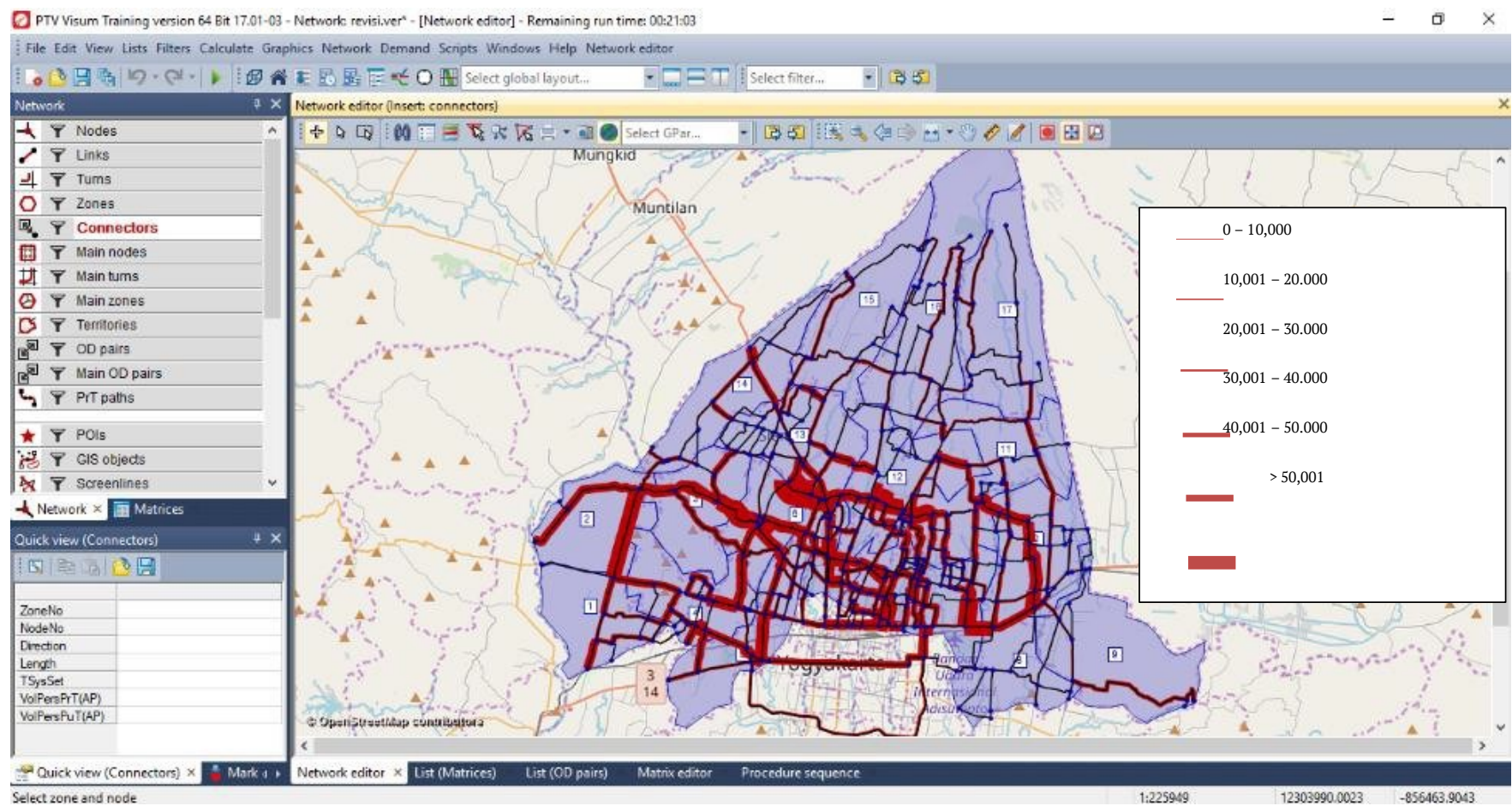

Figure 3: The Load of Traffic Network Based on OD Matrix

Figure 4 shows that a shorter route was designed for JORR. This study's proposed route had less distance of approximately $17 \mathrm{~km}$ from the length of the JORR route, which is $72.2 \mathrm{~km}$, with an alternative route of $55.3 \mathrm{~km}$. Therefore, the comparison of $V / C$ results in 2026 through 3 different methods are shown in Table 1, with the proposed speed of 2026 compared through 3 different methods is shown in Table 2.

Table 1 shows that almost all streets in 2026 were without the construction of JORR because the value of $\mathrm{V} / \mathrm{C}$ was above 0.85 . Therefore, with the government's construction of the planning routes, traffics at Jogja-Solo St and Magelang St reduced because the $V / C$ (volume/capacity) ratio was approximately $10 \%$. On the other hand, with the alternatives plan, the road performance increased by $50 \%$ at Jogja-Solo St despite making the worse comparison between Volume and capacity at Kaliurang St and Palagan St. The Equation (1) shows the calculation sample of the existing condition at Kaliurang street without JORR.

Based on the exponential growth of secondary data from DoT, obtained in 2018, Volume at 2026 is $2,694 \mathrm{pcu} / \mathrm{h}$ with $3,494 \mathrm{pcu} / \mathrm{hr}$ capacity.

$$
V / C \text { ratio }=\frac{2,694.6}{3,494}=0.7712
$$

However, irrespective of the incomplete speed comparison regarding the level of traffic performance shown in Table 2, some data were unavailable during the process. The speed from Directorate General Bina Marga (DGBM), MoPW of Indonesia in 1997, indicated that the construction of JORR reduces traffic congestion in some locations, such as Magelang St and Kaliurang St. Equation (2) shows the calculation process (2) at Kaliurang street, using the existing condition without JORR. The basic free-flow speed and adjustment factors based on the 1997 DGBM, and MoPW analysis, depends on the characteristics of the road.

$$
\begin{aligned}
F V & =\left(F V_{0}+F V_{W}\right) \times F F V_{S F} \times F F V_{C S} \\
& =(44+0) \times 0.79 \times 1 \\
& =37.76 \mathrm{~km} / \mathrm{h}
\end{aligned}
$$

From the free-flow speed and $V / C$ ratio at the previous calculation, the speed at Kaliurang St was $23 \mathrm{~km} / \mathrm{h}$, according to the correlation between $V / C$ and $F V$ of DGBM. 


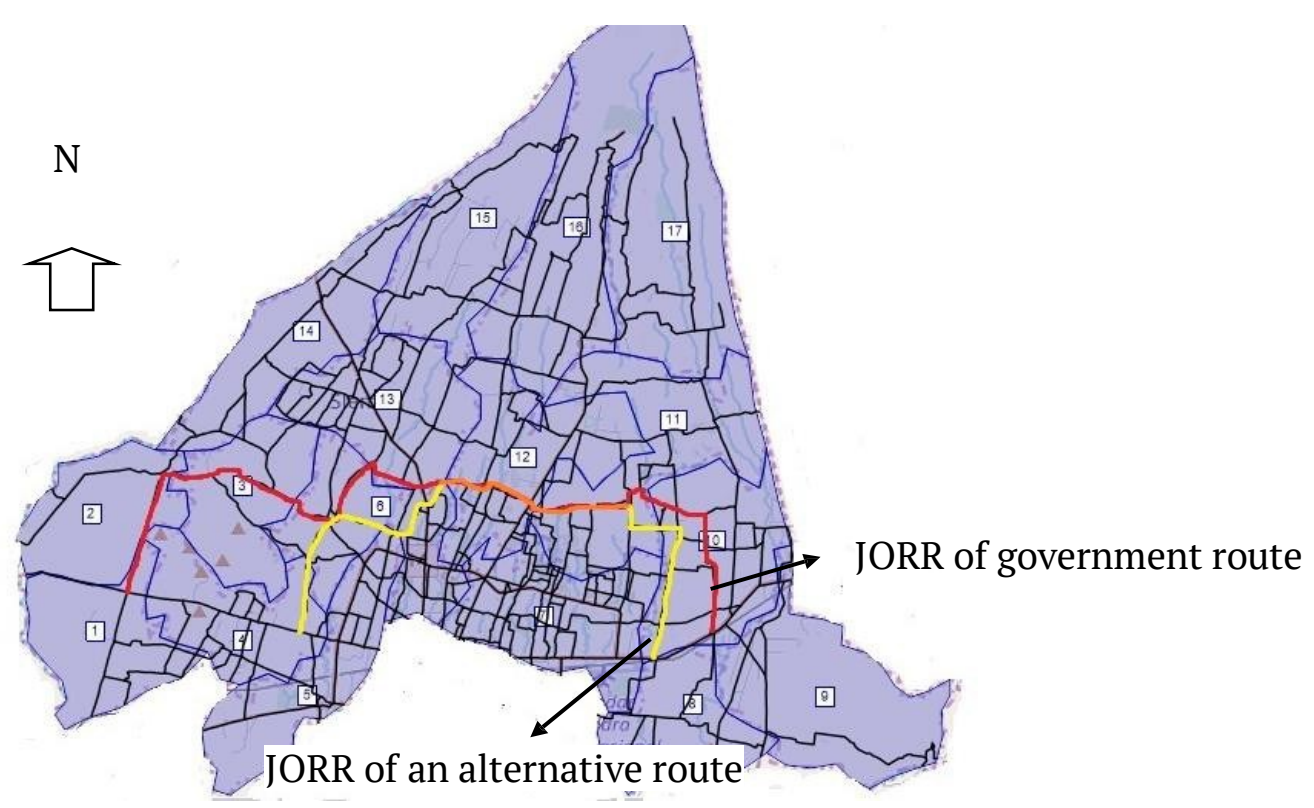

Figure 4: Planning Route from Government (red line) and Alternative Planning Route (yellow line)

Table 1: The Comparison of V/C Results in 2026

\begin{tabular}{|c|c|c|c|c|c|c|c|c|}
\hline \multirow[t]{2}{*}{ No } & \multirow[t]{2}{*}{ Road } & \multirow[t]{2}{*}{ Direction } & \multirow{2}{*}{$\begin{array}{l}\text { Capacity } \\
(\mathrm{pcu} / \mathrm{h})\end{array}$} & \multirow{2}{*}{$\begin{array}{l}\text { Without } \\
\text { JORR }\end{array}$} & \multicolumn{2}{|c|}{$\begin{array}{l}\text { With JORR of } \\
\text { Government Route }\end{array}$} & \multicolumn{2}{|c|}{$\begin{array}{l}\text { With JORR of Alternative } \\
\text { Route }\end{array}$} \\
\hline & & & & & $V / C$ at 2026 & Difference & $V / C$ at 2026 & Difference \\
\hline \multirow[t]{2}{*}{1} & \multirow{2}{*}{$\begin{array}{l}\text { Jogja- Solo St (in front of } \\
\text { Kalasan District) }\end{array}$} & East & 3,953 & 1.02 & 0.93 & $-9.00 \%$ & 0.39 & $-60.87 \%$ \\
\hline & & West & 3,953 & 1.30 & 1.22 & $-6.31 \%$ & 0.66 & $-49.29 \%$ \\
\hline 2 & $\begin{array}{l}\text { Kaliurang St (in front of } \\
\text { PLN) }\end{array}$ & & 3,494 & 0.77 & 0.87 & $13.82 \%$ & 1.39 & $81.42 \%$ \\
\hline 3 & $\begin{array}{l}\text { Palagan Tentara St (in } \\
\text { front of Hyatt Hotel) }\end{array}$ & & 3,494 & 1.20 & 1.78 & $48.67 \%$ & 1.70 & $41.81 \%$ \\
\hline \multirow[t]{2}{*}{4} & \multirow{2}{*}{$\begin{array}{l}\text { Magelang St (in front of } \\
\text { Wahidin Court) }\end{array}$} & North & 3,432 & 0.82 & 0.77 & $-5.85 \%$ & 0.89 & $9.23 \%$ \\
\hline & & South & 3,930 & 1.32 & 1.10 & $-16.30 \%$ & 1.25 & $-5.33 \%$ \\
\hline
\end{tabular}

Table 2: The Comparison of Speed Results in 2026

\begin{tabular}{llllll}
\hline \multirow{2}{*}{ No } & Road & Direction & $\begin{array}{l}\text { Without } \\
\text { JORR }\end{array}$ & $\begin{array}{l}\text { With JORR of Government } \\
\text { route }(\mathrm{km} / \mathrm{h})\end{array}$ & $\begin{array}{l}\text { With JORR of Alternative } \\
\text { Route }(\mathrm{km} / \mathrm{h})\end{array}$ \\
\hline \multirow{2}{*}{$\begin{array}{l}\text { Jogja - Solo St (in front of } \\
\text { Kalasan District) }\end{array}$} & $\begin{array}{l}\text { East } \\
\text { West }\end{array}$ & $\begin{array}{l}29.30 \\
21.25\end{array}$ & $\begin{array}{l}32.50 \\
19.94\end{array}$ & $\begin{array}{l}46.00 \\
42.00\end{array}$ \\
\hline \multirow{2}{*}{2} & $\begin{array}{l}\text { Kaliurang St (in front of } \\
\text { PLN) }\end{array}$ & & 23.00 & 25.00 & 14.00 \\
\hline \multirow{2}{*}{3} & $\begin{array}{l}\text { Palagan Tentara St (in } \\
\text { front of Hyatt Hotel) }\end{array}$ & & 15.40 & 11.00 & 12.10 \\
\hline \multirow{2}{*}{4} & Magelang St (in front of & North & 34.00 & 38.00 & 34.00 \\
& Wahidin Court) & South & 17.00 & 22.00 & 21.00 \\
\hline
\end{tabular}




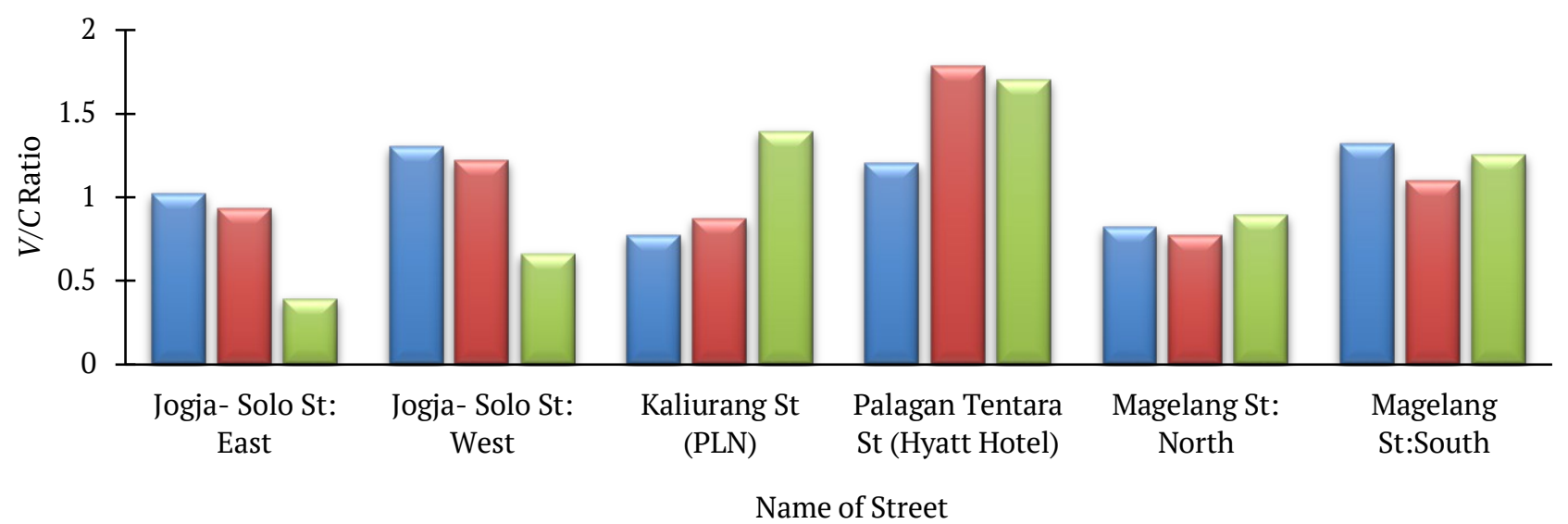

$\square$ Without JORR $\square$ With JORR of government route $\quad \square$ With JORR of alternative route

Figure 5: The Comparison of V/C Ratio at 2026

In 2026, the best achievement without JORR, based on the V/C ratio, was at Kaliurang St with less than 0.80 because the traffic volume and capacity were lower than others. Jogja-Solo St, with higher capacity, had a lower $\mathrm{V} / \mathrm{C}$ ratio than Kaliurang St due to a greater number of vehicles.

Figure 5 shows that in the $\mathrm{V} / \mathrm{C}$ ratio of arterial roads at Jogjakarta, the construction of JORR decreases the traffic congestion in some streets, such as at Jogja Solo St and Magelang St. On the other side, such as Kaliurang ST and Palagan Tentara Pelajar St, the performance seems worse with a higher value of $\mathrm{V} / \mathrm{C}$.

However, with a better V/C ratio, the speed of LV at Kaliurang St and Jogja-Solo St were in the opposite conditions. Therefore, in accordance with the results of this study, some suggestions are proposed as the push factor to reduce private vehicle usage and properly manage traffic congestion on the 4 target main roads. In addition, the actualization of public transportation maintenance is very necessary through the use of a modern public system such as 'Trans Jogja Bus.' There is no doubt that a wide range of factors influences public transport demand, with several empirical evidence indicating the relevant factors such as degree of uncertainty. One of the problems encountered during the study was in determining the context under which some of the reported experiments and studies were conducted. This was especially marked in accordance with the separated short and long-run effects. The whole issue provides further benefits to ascertain whether attribute valuations refer to the short or the long run(Paulley et al., 2006). The changes in the input variables performed in this research, such as income and car ownership, are the most important attributes that affect tour frequency and mode choice than a destination, thereby leading to broadly similar effects in terms of tours and kilometers(de Jong et al., 2007).

\section{CONCLUSION}

In conclusion, there is a possible increase in congestions at Yogyakarta without the construction of JORR in 2026. This is due to the high value of the $\mathrm{V} / \mathrm{C}$ ratio at Jogja Solo St (Kalasan District) with a V/C ratio of 1.02 and 1.30 to the east and west. In addition to Kaliurang St (State Electricity Company) with V/C ratio of 0.77 and low speed of $23 \mathrm{~km} /$ hour, as well as on Palagan Tentara Pelajar St (Hyatt Hotel) with V/C ratio of 1.20, and on Magelang St (Wahidin Court) with $\mathrm{V} / \mathrm{C}$ ratio of 0.82 and 1.32 to the north and south.

The application of JORR at some locations in Yogyakarta indicated raising conditions with a decrease in V/C ratio and higher speed in some locations. Nevertheless, the JORR route improvement with government proposal slightly increases the speed, although the increase was not as much as the alternative proposed route. On 
the other hand, in Kaliurang St, the alternative route of JORR showed that the performance was lower than the government's route.

Finally, a solution is needed to integrate traffic management with a private vehicle's push and pull factor by implementing a proper traffic management system on the 4 main roads, such as the disallowance for parking, stipulation of oneway scheme, and the actualization of public transportation. Further research on JORR construction in the south toned to be conducted for a better and deeper overview and illustration on Yogyakarta main roads, such as the effect of safety. Although new arterial roads induce more traffic, the advantage is significant because the rate of accidents is decreased (Amundsen and Elvik, 2004).

\section{DISCLAIMER}

The authors declare no conflict of interest.

\section{ACKNOWLEDGMENTS}

The authors thank to Local Department of Transportation, Daerah Istimewa Yogyakarta for providing data of this study.

\section{REFERENCES}

Amundsen, A. H. and Elvik, R, 2004. Effects on Road Safety of New Urban Arterial Roads. Accident Analysis and Prevention Journal, 36(1), pp. 115-123.

Arliansyah, J., Prasetyo, M. R. and Kurnia, A. Y., 2017. Planning of city transportation infrastructure based on macro simulation model. International Journal on Advanced Science, Engineering and Information Technology, 7(4), pp. 1262-1267.

Çolak, S., Lima, A., \& González, M. C., 2016. Understanding Congested Travel in Urban Areas. Nature Communications Journal.

De Jong, G., Daly, A., Pieters, M., Miller, S., Plasmeijer, R. and Hofman, F. 2007. Uncertainty in traffic forecasts: Literature review and new results for The Netherlands, Transportation, 34(4), pp. 375-395.
Directorate General of Bina Marga., 1997. Manual Kapasitas Jalan Indonesia (MKJI). Bina Marga Publisher. Jakarta. Indonesia

Dowling, R., Skabardonis, A., \& Alexiadis, V., 2004. Traffic Analysis Toolbox Volume III: Guidelines for Applying Traffic Microsimulation Modeling Software. Rep. No. FHWA-HRT-04-040, U.S. DOT, Federal Highway Administration, Washington, D.C, III(July), 146.

Fitrada, A.G, Munawar A, Dewanti., 2019. Investigating the Impact of Airport Relocation on the Transport Network in Special Region of Yogyakarta, Indonesia. Journal of The Civil Engineering Forum, 5(2), pp.93-104.

Fuady, B.H., 2015. Transportation Characteristics of Banyuasin Regency, Buffer City of Palembang City. Thesis (Unpublished). Department of Civil Engineering. Universitas Sriwijaya.

Fontes, T., Pereira, S. R., Fernandes, P., Bandeira, J. M., \& Coelho, M. C., 2015. How to Combine Different Microsimulation Tools to Assess the Environmental Impacts of Road Traffic? Lessons and Directions. Transportation Research Part D: Transport and Environment, 34, 293-306.

Gajjar and Mohadash., 2016. Critical Assessment of Road Capacities on Urban Roads - A Mumbai Casestudy, Transportation Research Procedia, 17, 2016, pp. 685-692,

Grigonis, V., Burinskiene, M., Paliulis, G., Ušpalyte-Vitkuniene, R., Dumbliauskas, V. and Barauskas, A., 2014. Modelling a passenger car system based on the principles of sustainable mobility in Vilnius City. Transport, 29(3), pp. 334-341.

de Jong, G., Daly, A., Pieters, M., Miller, S., Plasmeijer, R. and Hofman, F., 2007. Uncertainty in traffic forecasts: Literature review and new results for The Netherlands. Transportation, 34(4), pp. 375-395.

Hendra, Y.N.R., 2017. Evaluasi Rencana Pembangunan Jalan Lingkar di Kota Banda Aceh. Jurnal Himpunan Pengembangan Jalan Indonesia, 3, pp.37-46. 
Hobbs, F.D., 1974. Traffic Planning and Engineering. Oxford: Pergamon Press Ltd Publisher.

Hollander, Y., \& Liu, R., 2008. The Principles of Calibrating Traffic Microsimulation Models. Journal of Transportation, 35(3), pp. 347-362.

Jain, V., Sharma, A., \& Subramanian, L., 2012. Road Traffic Congestion in The Developing World. Proceedings of the 2nd ACM Symposium on Computing for Development, DEV 2012.

Jiḿenez, D., Mũnoz, F., Arias, S., \& Hincapie, J, 2016. Software for Calibration of Transmodeler Traffic Microsimulation Models. IEEE Conference on Intelligent Transportation Systems, Proceedings, ITSC, pp. 1317-1323.

Lindsney, R. \& Verhoef, E ., 2001, Traffic Congestion And Congestion Pricing, Button, K.J. and Hensher, D.A. (Ed.) andbook of Transport Systems and Traffic Control. (3), Emerald Group Publishing Limited, pp. 77-105.

O'Flaherty, C.A., 1997. Transport Planning and Traffic Engineering. Oxford: Elsevier Ltd Publisher.

Ortuzar, J.D., Luis G. Willumsen., 2011. Modelling Transport, Fourth Edition. London: John Wiley \& Sons Ltd Publisher.

Paulley, N., Balcombe, R., Mackett, R., Titheridge, H., Preston, J., Wardman, M., Shires, J. and White, P., 2006. The demand for public transport: The effects of fares, quality of service, income and car ownership. Transport Policy, 13(4), pp. 295-306.

Praditya, N.D.A., 2017. Pemodelan Transportasi Mode Sepeda Motor Kota Samarinda untuk Tahun 2016. Thesis (Unpublished). Institut Teknologi Sepuluh Nopember.

PTV AG, 2011. PTV VISION VISUM 11.52Fundamentals. German:PTV AG.

Rao, A. M., Velmurugan, S. and Lakshmi, K. M. V. N., 2017. Evaluation of Influence of Roadside Frictions on the Capacity of Roads in Delhi, India, Transportation Research Procedia. Elsevier B.V.,
25, pp. 4771-4782.

Savrasov, M., 2007. Development of Liepaja City Macroscopic Model for Decision-Making", Transport and Telecommunication, 8, p.38-46.

Sánchez-Medina, J. J., Galán-Moreno, M. J., \& Rubio-Royo, E., 2010. Traffic signal optimization in la Almozara District in Saragossa under congestion conditions, using genetic algorithms, traffic microsimulation, and cluster computing. IEEE Transactions on Intelligent Transportation Systems,11(1),132-141.

Stopher, P. R., 2004. Reducing road congestion: A reality check. Transport Policy.

Tamin, O.Z., 1997. Perencanaan dan Pemodelan Transportasi. Bandung: ITB Publisher

Taplin, J., 1999. Simulation Models of Traffic Transportation.

Tennøy, A., Tønnesen, A. and Gundersen, F., 2019. Effects of urban road capacity expansion Experiences from two Norwegian cases, Transportation Research Part D: Transport and Environment. Elsevier, 69(2), pp. 90-106.

Thamizh Arasan, V., Wermuth, M. and Srinivas, B. S., 1996. Modeling of stratified urban trip distribution, Journal of Transportation Engineering.

Transportation Research Board., 2000. Highway Capacity Manual. National Academy of Science Publisher. Washington DC.

Wang, C., Quddus, M. A. and Ison, S. G., 2009. Impact of traffic congestion on road accidents: A spatial analysis of the M25 motorway in England', Accident Analysis and Prevention.

Yatski, I., Mihail Savrasov., 2010. Development of Riga-Minsk Transport Corridor Simulation Model", Transport and Telecommunication, 11, p.38-47.

Yunus, G.A.U, et al., 2018. Transportation Modelling on the Trans Bangka Road Using PTV Visum Application, Reka Racana, 4,p.83-94. 
[This page is intentionally left blank] 